\title{
REDISCOVERY OF THE RARE STONEFLY UTAPERLA SOPLADORA AT THE TYPE LOCALITY MORE THAN HALF A CENTURY AFTER IT WAS DESCRIBED
}

\author{
Richard W. Baumann ${ }^{1}$
}

Key words: Utah, stonefly, Plecoptera, Utaperla sopladora.

Utaperla sopladora Ricker was named as a monotypic genus and species from a holotype male, with the type locality given as Puffer's Lake, Utah (Ricker 1952). A 2nd specimen from the Yukon River, Dawson, Yukon Territory, Canada was available to Bill Ricker when he named the species. This female paratype was designated as the allotype, and Ricker stated that he had "little hesitation in describing the latter under the same name." Time has borne out the validity of Ricker's statement, since subsequent collections between northern Canada and Utah have produced specimens that all seem conspecific (Gaufin 1964, Gaufin et al. 1972, Ricker and Scudder 1975, Baumann et al. 1977, Stewart and Ricker 1997). Additionally, Ricker (1976) gave the etymology of the binomial name: Utaperla means the perlid from Utah, since the type species is from Utah, and sopladora is derived from the Spanish word sopladór translated as "puffer."

The Puffer Lake (Beaver County, Utah) locality is easily the most southern distribution point for this rare species. Most collections of $U$. sopladora are from much more northern latitudes and usually from high elevations (Ricker and Scudder 1975, Baumann et al. 1977, Donald and Anderson 1977). Ricker (1964) and Nelson and Hanson (1969) speculated that $U$. sopladora was originally a northern species that survived the ice age in unglaciated refugia and subsequently moved southward along the Rocky Mountain chain. The Nevada record (Surdick and Cather 1975) is from the Ruby Mountains near Elko in Elko County, a range which has faunal affinities with the central Rocky Mountains (Nelson and Baumann 1989). Additionally, Surdick and Cather (1975) was a valuable contribution because it included the description of a mature male nymph. Overall, this species is very poorly known throughout its range, because it is rarely encountered by the average collector. Utaperla sopladora, with black color and long cerci, is often mistaken for a member of the family Capniidae. It is not known from Colorado, Arizona, or New Mexico.

Utah presents an interesting picture of the total known distribution of U. sopladora. It was found to occur sporadically in the Raft River Mountains of extreme northwestern Utah (Houseman and Baumann 1997). These mountains are located in the Columbia Plateau region, which is the only portion of the state that drains into the Columbia River drainage. Besides the type locality in the Beaver Mountains, U. sopladora was only recorded at 1 other site in southern Utah (Call and Baumann 2002): a single female was found at the headwaters of Thistle Creek on the Wasatch Plateau. Although major efforts were made to re-collect this species near Puffer Lake, no specimens were found. Thus, in July 2005 it was a great benefit to collect 6 males and 2 females at Lake Stream approximately $1 \mathrm{~km}$ above where it enters Puffer Lake at $38^{\circ} 19^{\prime} \mathrm{N}, 112^{\circ} 21^{\prime} \mathrm{W}$. This confirms its presence at the type locality 62 years after the type was collected by George Knowlton (Ricker 1952). The collection site is in Fishlake National Forest, but access is through private land and permission is required. The only other known Utah records of $U$. sopladora are from the Uinta Mountains at the headwaters of the Provo River, the Bear River, and the Blacks Fork of the Green River. Interestingly, although the Wasatch Mountains of northern Utah are probably the most heavily collected mountains

${ }^{1}$ Department of Integrative Biology and Monte L. Bean Life Science Museum, Brigham Young University, Provo, UT 84602. 
in North America for Plecoptera, this species has never been recorded. Early efforts by James Needham and George Knowlton, near Utah State University, Logan (Needham and Christensen 1927); studies by Arden Gaufin and colleagues at the University of Utah, Salt Lake City (Gaufin et al. 1966); and extensive collecting by myself, colleagues, and students at Brigham Young University, Provo, Utah, have all failed to produce a single specimen from the Wasatch Mountains.

The genus Utaperla currently includes 3 species: Utaperla sopladora Ricker (1952), western North America; Utaperla orientalis Nelson and Hanson (1969), China; and Utaperla gaspesiana Harper and Roy (1975), northeastern North America.

Special thanks to Bill Stark of Mississippi College, Clinton, and Rebecca Surdick of Entomological Laboratory, White Post, Virginia, for sharing Utah collection records of Utaperla sopladora.

\section{Literature Cited}

Baumann, R.W., A.R. Gaufin, and R.F. Surdick. 1977. The stoneflies (Plecoptera) of the Rocky Mountains. Memoirs of the American Entomological Society 31:1-208.

Call, R.G., and R.W. Baumann. 2002. Stoneflies (Plecoptera) of southern Utah, with an updated checklist of Utah species. Monographs of the Western North American Naturalist 1:65-89.

Donald, D.B., AND R.S. Anderson. 1977. Distribution of the stoneflies (Plecoptera) of the Waterton River drainage, Alberta, Canada. Syesis 10:111-120.

Gaufin, A.R. 1964. The Chloroperlidae of North Amerika. Gewässer und Abwässer 34/35:37-49.
Gaufin, A.R., A.V. Nebeker, And J. Sessions. 1966. The stoneflies (Plecoptera) of Utah. University of Utah Biological Series 14:1-93.

Gaufin, A.R., W.E. Ricker, M. Miner, P. Milam, and R.A. HAYs. 1972. The stoneflies (Plecoptera) of Montana. Transactions of the American Entomological Society 98:1-161.

HaRPER, P.P., AND D. Roy. 1975. Utaperla gaspesiana sp. nov., le premier Plécoptère Paraperliné de l'Est canadien. Canadian Journal of Zoology 53:1185-1187.

Houseman, R.M., AND R.W. BaUmanN. 1997. Zoogeographic affinities of the stoneflies (Plecoptera) of the Raft River Mountains, Utah. Great Basin Naturalist 57: 209-219.

Needham, J.G., and R.O. Christensen. 1927. Economic insects in some streams of northern Utah. Utah Agriculture Experiment Station Bulletin 201:1-36.

Nelson, C.R., And R.W. Baumann. 1989. Systematics and distribution of the winter stonefly genus Capnia (Plecoptera: Capniidae) in North America. Great Basin Naturalist 49:289-363.

Nelson, C.H., and J.F. Hanson. 1969. The genus Utaperla (Plecoptera: Chloroperlidae. Pan-Pacific Entomologist 45:26-34.

Ricker, W.E. 1952. Systematic studies in Plecoptera. Indiana University Publications, Science Series 18: $1-200$.

1964. Distribution of Canadian stoneflies. Gewässer und Abwässer 34/35:50-71.

. 1976. Origin of stonefly names proposed by Ricker and collaborators. Perla 2:5-19.

RickER, W.E., AND G.G.E. ScUDDER. 1975. An annotated checklist of the Plecoptera (Insecta) of British Columbia. Syesis 8:333-348.

Stewart, K.W., and W.E. Ricker. 1997. Stoneflies (Plecoptera) of the Yukon. Pages 201-222 in H.V. Danks and J.A. Downes, editors, Insects of the Yukon. Biological Survey of Canada, Ottawa.

Surdick, R.F., AND M.R. Cather. 1975. The nymph of Utaperla sopladora Ricker (Plecoptera: Chloroperlidae). Entomological News 86:102-106.

Received 16 September 2005 Accepted 24 January 2006 